ADALAH : Buletin Hukum \&

Keadilan

@adalahuinjkt

buletin.adalah

\title{
Faktor Pendorong Terjadinya Insurgensi Di Suatu Wilayah
}

Sekar Hapsari*

Insurgensi merupakan salah satu wujud peperangan asimetris. Fenomena gerakan insurgensi pada prinsipnya adalah perjuangan politik yang dilakukan oleh sekelompok masyarakat dalam suatu wilayah negara terhadap pemerintah yang memiliki suatu otoritas yang berdaulat. Insurjensi merupakan pergerakan politik sebagai hasil dari ketidakpuasan dan penolakan dari kebijakankebijakan yang ditetapkan oleh suatu pemerintah atau negara. Gerakan insurjensi juga memiliki akar permasalahan yang kompleks dan berbeda-beda serta dilakukan dalam berbagai bentuk (Fadilah, 2006: 13).

Dalam sejarahnya, gerakan insurjensi pada awalnya dipandang sebagai gerakan perlawanan yang menggunakan kekuatan bersenjata yaitu dengan cara kekerasan untuk melawan pemerintahan yang sah. namun seiring berkembangnya zaman, perlawanan dengan kekuatan bersenjata berkembang menjadi sebuah gerakan pemberotakan atau insurjensi yang memiliki maksud-maksud politik untuk menggulingkan rezim yang berkuasa (Sasongko, 2013: 1).

Insurjensi dapat dipandang sebagai sebuah sistem operasi yang mengolah input untuk mendapatkan output. Input dari dalam (endogeny) seperti rekrutmen, suplai logistik, tempat tinggal, informasi dan lain sebagainya

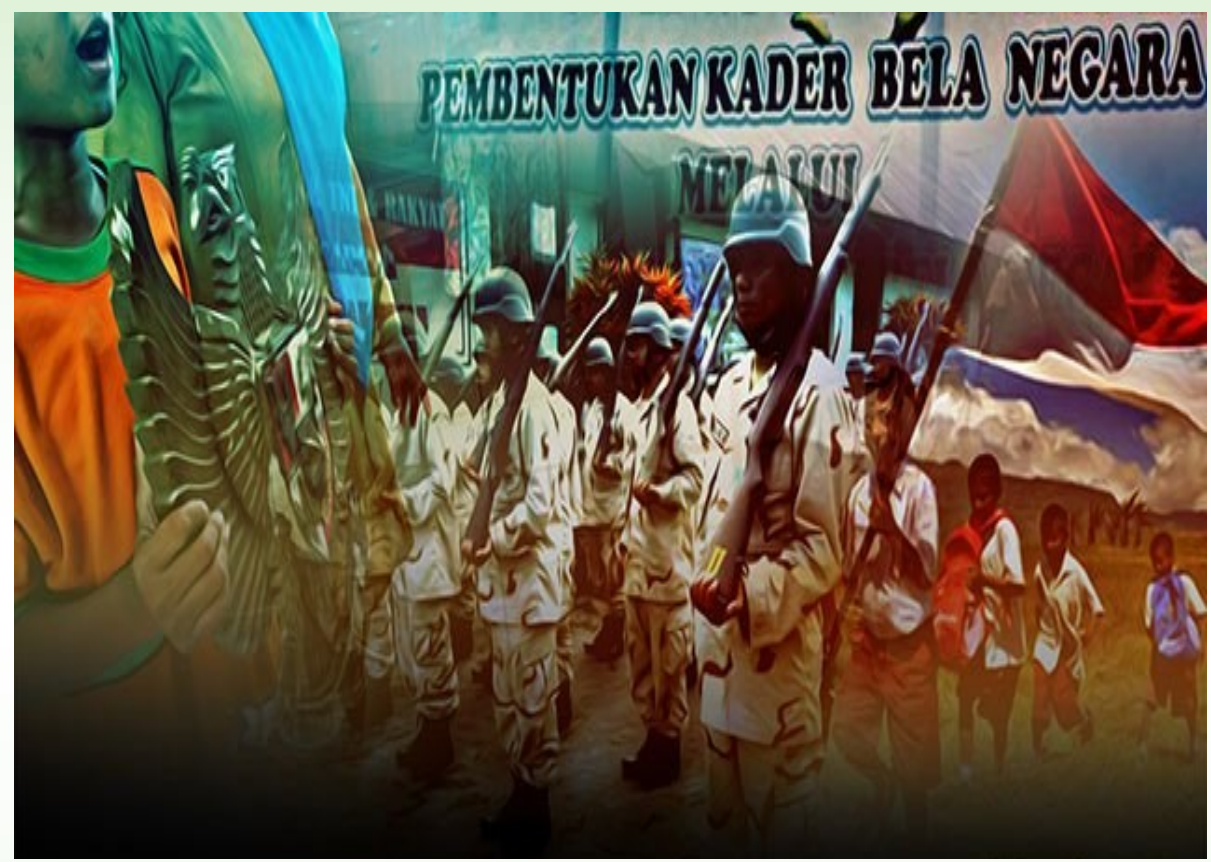

diperoleh dalam jumlah yang bervariasi kemudian diolah untuk menjadi output tertentu. Untuk medapatkan input dari daerah setempat, dilakukan aneka teknik persuasif maupun koersif. Kadangkala tindakan koersif yang keras dikombinasikan dengan tindakan persuasif yang efektif dan meyakinkan guna mendapat dampak yang diinginkan.

Perkembangan insurgensi di era modern dipengaruhi oleh urbanisasi, globalisasi, dan perkembangan informasi. Perbedaan yang signifikan antara insurgensi modern dan insurgensi klasik terletak pada tiga aspek tersebut. Globalisasi yang menjadi fenomena pergeseran peradaban dengan berkembangnya budaya masyarakat
Perkembangan teknologi, ekonomi, politik dan budaya mendorong terjadinya pergeseran gerakan insurgensi di suatu negara.

Faktor ini menyebabkan interaksi masyarakat dunia yang tidak terbatas lagi oleh batas wilayah antar negara. Efek dari globalisasi dapat memberikan pengaruh kepada lingkungan operasional dari gerakan insurjensi semakin modern. Selain perkembangan ilmu pengetahuan dan teknologi yang dapat dimanfaatkan bagi kelompokkelompok gerakan insurjensi guna mencapai tujuan strategisnya, seperti pemanfaatan jaringan komputer dan internet. Dengan kemodernan ini mereka membentuk jaringan kelompok insurjensi internasional yang berkaitan satu 
sama lainnya, sehingga berakibat mereka mendapat kemudahan dan dukungan aliran dana, persenjataan, penggalangan, pelatihan militer, serta jaringan kerja yang luas, yang tidak lagi berbatas wilayah antar negara.

Tren urbanisasi, globalisasi, dan revolusi informasi semua menjurus pada satu titik fokus insurjensi di masa depan yaitu lingkungan perkotaan. Ketiga hal ini dianggap sebagai faktor pendorong terjadinya insurjensi di suatu wilayah.

Faktor pendorong pertama yaitu urbanisasi. Hal ini terlihat dalam aksi terorisme di Indonesia pada tahun 2002 dengan diawali oleh kasus Bom Bali yang menewaskan ratusan korban jiwa. Sebagian digunakan untuk menggambarkan adaptasi insurjensi sebagai reaksi terhadap kebencian terhadap Amerika Serikat dan orang-orang non muslim di Indonesia. Di dalam aksi tersebut kekuatan bersenjata kecil yang didirikan mengarah ke suksesi insurjensi.

Teori

Abraham

$$
\text { insurjensi perkotaan, }
$$

dan miskin dalam suatu negara. Meskipun ini mungkin tidak menjadi akibat langsung dari globalisasi, namun kesenjangan ketimpangan pendapatan berpotensi bagi eksploitasi para pelaku insurjensi, baik di negara maju maupun negara berkembang. Globalisasi digunakan dengan mengintegrasikan aspek teknologi yang diperlukan seperti komunikasi, spesifik pasar, dan pergerakan orang, juga menjadikan para insurjensi sebagai target di perkotaan.

Faktor pendorong ketiga yaitu perkembangan informasi. Perkembangan informasi erat kaitannya dengan interkoneksi dalam globalisasi. Bukan hanya dimensi ekonomi saja, tetapi juga politik dan budaya. Contoh perkembangan informasi adalah Internet dan
Marighella menyatakan bahwa pada kondisi masa lalu merupakan syarat pencampuran baik di pedesaan dan perkotaan. Insurjensi perkotaan memulai "revolusi" ini boleh jadi tidak untuk saat sekarang, karena negaranegara dilihat perkembangan sekarang dari jumlah penduduk dan dampak urbanisasi.

Strategi perang perkotaan umumnya merupakan aplikasi sistematis teror taktik dalam lingkungan perkotaan untuk mengikis kehendak pemerintah yang berkuasa dan kemampuan untuk menahan insurjensi dan mendelegitimasi pemerintah di mata populasi. Mobilisasi dukungan rakyat adalah penting dalam strategi ini, tapi sulit, karena sarana untuk mencapai dukungan ini lebih terbatas untuk opsi militer dari indoktrinasi politik atau cooption.

Faktor kedua adalah Globalisasi. Globalisasi mengacu pada integrasi peningkatan ekonomi dunia. Pergerakan orang menggunakan informasi yang dapat melintasi perbatasan internasional. Di paruh kedua abad kedua puluh telah ada pertumbuhan pendapatan rata-rata global yang signifikan. Namun, ada juga ketimpangan pendapatan yang signifikan di bawah kesenjangan antara negara kaya dan negara-negara miskin, serta kesenjangan pertumbuhan antara kaya media massa. Perkembangan informasi tidak hanya memungkinkan bagian dari informasi dan propaganda global secara real time, tetapi juga menyediakan kerentanan, penyimpangan informasi, dan sistem kontrol guna mewujudkan format digitalisasi yang lebih besar. Selain itu melalui media informasi akan memudahkan masuknya budaya asing yang lebih besar dari sebelumnya, baik melalui televisi, radio, maupun internet. Akibatnya timbul ketidakseimbangan bahkan kesenjangan antara harapan nilai dan kemampuan nilai masyarakat. Hal ini dapat menyebabkan konflik dari kenaikan ekspektasi dalam masyarakat. Oleh karenanya timbul hal-hal yang memicu gerakan insurjensi pada lapisan masyarakat tertentu.[]

\section{Pustaka Acuan:}

*Penulis adalah mahasiswa Program PhD. Kazan Federal University, Russia, sekaligus peneliti bidang Hukum Pertahanan dan Militer.

Fadilah, Agus. Pemberontakan dan Kontra Insurjensi, Jakarta: FRR Law Office, 2006.

Sasongko, Sigit. "Diplomasi Insurjensi Dalam Peperangan Asimetris," Vol. 1 No. 1 Desember (2013).

'Adalah; Buletin Hukum dan Keadilan merupakan berkala ilmiah yang diterbitkan oleh Pusat Studi Konstitusi dan Legislasi Nasional (POSKO-LEGNAS), Fakultas Syariah dan Hukum UIN Syarif Hidayatullah Jakarta.

Penasehat: Prof. Dr. H. Abdul Ghani Abdullah, SH., Prof. Dr. H. A Salman Maggalatung, SH., MH. Pemimpin Redaktur: Indra Rahmatullah, Tim Redaktur: Nur Rohim Yunus, Fathuddin, Mara Sutan Rambe, Muhammad Ishar Helmi, Erwin Hikmatiar. Penyunting: Latipah, Siti Nurhalimah. Setting \& Layout: Siti Romlah 